\title{
Correlation Between Serum Ferritin Level and Vitamin D Hydroxycholecalciferol (25OH) Level in Children with Transfusion Dependent Thalassemia
}

\author{
Raden Muhammad Zulfan Jauhari ${ }^{1}$, Andi Cahyadi ${ }^{1}$, Mia Ratwita Andarsini ${ }^{1}$, IDG \\ Ugrasena $^{1}$, Maria C.S Larasati ${ }^{1}$ \\ official email address: Radenzulfan.rz@gmail.com
}

1Child Health Department, Medical Faculty, Airlangga University/Dr. Soetomo General Hospital, Surabaya 60286-Indonesia

\begin{abstract}
Background: Transfusion dependent thalassemia (TDT) patients will progressively experience iron overload due to repeated blood transfusions. It also causes vitamin D hydroxycholecalcoferol $(25 \mathrm{OH})$ depletion in the liver parenchyma.

Methods: This was a cross-sectional study of children with TDT in Hemato-oncology outpatient clinic, Dr. Soetomo Hospital Surabaya which has enrolled in the study from January-june 2020. Serum ferritin level by Enzym linked Fluorescent Assay (ELFA) and vitamin D hydroxycholecalciferol $(25 \mathrm{OH})$ level was examined by the ADVIA centaur VitD assay method. To determine the correlation between serum ferritin level and vitamin D hydroxycholecalciferol $(25 \mathrm{OH})$ Spearman correlation was used, significant if $\mathrm{p}<0.05$
\end{abstract}

Results: There were 11 boys and 19 girls with TDT, their age ranged between 7-18 years old. The mean value of serum ferritin level was 2570 (SD 1805.6) $\mathrm{ng} / \mathrm{ml}$, and serum vitamin D hydroxycholecalciferol (25OH) was 16 (SD 8.06) $\mathrm{nmol} / \mathrm{ml}$. 26/30 subjects had serum ferritin level > $1000 \mathrm{ng} / \mathrm{ml}, 12 / 30$ subjects were considered deficient in vitamin D hydroxycholecalciferol $(25 \mathrm{OH})$, with vitamin D hydroxycholecalciferol $(25 \mathrm{OH})$ level $<15 \mathrm{nmol} / \mathrm{ml}$. The serum ferritin level had a negative correlation with vitamin D hydroxycholecalciferol $(25 \mathrm{OH})$ level $(\mathrm{r}=-0.476 ; \mathrm{p}<0.008)$.

Conclusion: Increased serum ferritin followed by decreased vitamin D hydroxycholecalciferol (25OH) in children with TDT

Keywords: Thalassemia, Child, Ferritin, vitamin D hydroxycholecalciferol (25OH) 


\section{Introduction}

Thalassemia is a hereditary anemia disease caused by a reduction in the synthesis of one or more globin chains that form the tetramer of hemoglobin. Thalassemia syndrome is named according to the globin chain of hemoglobin involved. Globin- $\beta$ gene defects cause $\beta$-thalassemia, while globin- $\alpha$ gene mutations cause $\alpha$ thalassemia [1]. The number of thalassemia patients in the hemato-oncology division, Dr. Soetomo General Hospital Surabaya had an increasing trend between 2009-2013 and recorded 267 patients.

In the long term, repeated blood transfusions can cause excess iron in various organs, causing damage to the organs and even death [3] [4] [5] [6]. The determination of serum or plasma ferritin concentration is the most frequently used method for indirect estimation of iron stores in the body in transfusion-dependent thalassemia patient management who receive routine blood transfusions accompanied by or iron-binding therapy [7].

Thalassemia patients are those who progressively experience excess iron in the liver parenchyma, heart, and endocrine organs [8] [9]. The accumulation of excess iron in the liver disrupts the hydroxylation of vitamin D [8 [9] [10] [11]. A study conducted by Prapai et al., stated that transfusion-dependent thalassemia patients aged 11-18 years showed a significant association between increased serum ferritin levels and decreased vitamin D hydroxycholecalciferol (25OH) [12].

Our study aimed to determine a correlation between serum ferritin levels and serum vitamin D hydroxycholecalciferol $(25 \mathrm{OH})$ in transfusion-dependent thalassemia patients.

\section{Subjects and Methods}

\subsection{Study Design}

The research design used a cross-sectional design, carried out in January-June 2020 with a consecutive sampling of thalassemia children who went to the hemato-oncology poly at Dr. Soetomo General Hospital Surabaya, whose parents had approved their child's participation in the study after given an explanation and signed informed consent. Data were obtained through history taking, physical examination, supporting examinations, and medical records. This research was approved by the Health Research Ethics Committee (KEPK) Dr. Soetomo General Hospital Surabaya with the number 1980 / KEPK / IV / 2020.

\subsection{Study Participants}

Based on the sample size formula to determine the correlation, we obtained 30 subjects. With the inclusion criteria: boys and girls with transfusion-dependent thalassemia, both $\beta$-thalassemia and $\alpha$ thalassemia who have hemoglobin electrophoresis examination, are less than 18 years of age who underwent blood transfusions during the study, and had received approval from their parents. The exclusion criteria were malignancy, or those receiving immunosuppressant therapy and neurological disorders.

\subsection{Laboratory Examination}

Iron deposits bound in plasma proteins were measured using the ELFA (Enzyme-Linked Fluorescent Assay) technique using a VIDAS tool. The test was conducted in the GDC laboratory of Dr. Soetomo General Hospital Surabaya. As much as $3 \mathrm{ml}$ of peripheral venous blood in a vacuum tube without anticoagulant was sent to the laboratory to be checked for ferritin levels. The output ferritin levels are in 
the form of numerical data. Serum 25-(OH)D level was measured by using enzyme-linked fluorescence assay (ELFA) methods with bio Mérieux VIDAS® 25 OH Vitamin D Total reagent (lot No. 190318-0). Sampling was done by collecting $100 \mu \mathrm{L}$ of peripheral serum collected in BD Vacutainer® blood sampling tube. Quality control was supervised by the Clinical Pathology Department of Dr. Soetomo General Hospital. Vitamin D status was determined based on serum 25-(OH)D level according to the Endocrine Society, which is categorized as deficient $(<20 \mathrm{ng} / \mathrm{ml})$, insufficient $(20-29 \mathrm{ng} / \mathrm{ml})$, and normal $(>29 \mathrm{ng} / \mathrm{ml})$ [9].

\subsection{Statistical analysis}

The analysis was performed using the Statistical Program for Social Science (SPSS) version 22.0. Before any data analysis, Spearman test was further used to analyze the correlation between ferritin serum and vitamin D hydroxycholecalciferol $(25 \mathrm{OH})$. The result is considered statistically significant under $\mathrm{p}$ $<0.05$.

\section{Results}

\subsection{Characteristic of patients}

This study involved 30 subjects aged 7-18 years, consisting of 11 boys and 19 girls. Based on Table.1 the mean age was 11.9 years and the age of diagnosis was 5.6 years. Patients had suffered from thalassemia for approximately 6.69 years, and considering the nutritional status, most thalassemia patients had less or good nutritional status. [Table 1]

Table 1. Characteristic of Subject

\begin{tabular}{lc}
\multicolumn{1}{c}{ Patient characteristic } & n \\
\hline Gender & $11 / 30$ \\
Male & $19 / 30$ \\
Female & $11.96 \pm 2.99$ \\
Current age (mean \pm SD) & $5.6 \pm 2.94$ \\
Age at diagnosis (mean \pm SD) & \\
Nutritional status & $4 / 30$ \\
Malnutrition & $13 / 30$ \\
Poor nutrition & $13 / 30$ \\
Good nutrition & $2570.4 \pm 1805.6$ \\
Average Ferritin levels $($ mean \pm SD) & $16.62 \pm 8.06$ \\
Vitamin D levels & \\
\hline
\end{tabular}


3.2 Correlation between serum ferritin levels and levels of Vitamin D hydroxycholecalciferol (25OH).

In table 2, the statistical analysis with the Spearman correlation test was presented to determine the relationship between serum ferritin levels and vitamin D hydroxycholecalciferol $(25 \mathrm{OH})$. Both had a strong negative correlation and was statistically significant $(\mathrm{p}=0.008 ; \mathrm{r}=-0.476)$ [Table 2]

Table 2. Correlation between serum ferritin levels and levels of Vitamin D hydroxycholecalciferol $(25 \mathrm{OH})$

Independent Variable $\quad$ Dependent Variable $\quad$ Sig

\begin{tabular}{ccc}
\hline Serum Ferritin Levels & Vitamin D Hydroxycholecalciferol & 0.008 \\
$(\mathbf{2 5 O H})$ Levels & $-0.476^{*}$ \\
& \\
\hline
\end{tabular}

*Spearman test

\section{Discussion}

In the general characteristics of the subjects $26 / 30$ subjects had serum ferritin levels $>1000 \mathrm{ng} / \mathrm{ml}, 12 / 30$ subjects had vitamin D hydroxycholecalciferol $(25 \mathrm{OH})<15 \mathrm{nmol} / \mathrm{ml}$. In transfusion-dependent thalassemia patients, long-term blood transfusions resulted in the transferrin capacity to bind and neutralize the vessels to be greatly reduced so that non-transferrin bound iron (NTBI) is formed in plasma and intracellularly in the form of a labile iron pool (LIP). These protein fractions cause cell and tissue damage through the release of hydroxyl free radicals. Free radicals formed through the Fenton reaction cause DNA oxidation, mitochondrial damage, membrane lipid peroxidation, which can damage organs and eventually cause cell death. Another effect is to increase growth factor $\beta 1$ which will increase collagen synthesis and fibrosis in various organs such as the heart, liver, and endocrine glands [11] [14] [15] [16].

Increased serum ferritin levels indicate the body's iron reserves. Iron reserves in the body correlate with serum ferritin levels, intracellular ferritin is produced by smooth endoplasmic reticulum (SER) and plasma ferritin is synthesized by rough endoplasmic reticulum (RER) and is delocalized by the Golgi apparatus. Under normal circumstances, the amount of plasma ferritin that is synthesized and secreted is proportional to the amount of cellular ferritin produced in the internal iron storage pathway, so that the plasma ferritin concentration is related to the accumulation of iron in the body [17] [18] [19] [20].

In this study, the serum ferritin levels obtained were 2570.4 (SD 1805.6) ng/ml, with an increase in serum ferritin levels $>1000 \mathrm{ng} / \mathrm{ml}$ in 26 of 30 subjects. High serum ferritin levels can be caused by increased absorption of iron in the gastrointestinal tract and excessive amounts of iron due to repeated red blood cell transfusions. The presence of excess iron in the liver disrupts the hydroxylation of vitamin D hydroxycholecalciferol $(25 \mathrm{OH})$. The disruption of the hydroxylation process of cholecalciferol $\left(\mathrm{D}_{3}\right)$ in the right position of 25 (top right of the molecule) to form 25 -hydroxycholecalciferol $\{25(\mathrm{OH}) \mathrm{D}\}$ which is released into the plasma is then hydroxylated in the kidneys, into an active form in the form of calcitriol. This is caused by a disrupted catalyzation process by the microsomal enzyme vitamin D 25-hydroxylase produced by hepatocytes [10] [22]. 
The level of vitamin D hydroxycholecalciferol $25(\mathrm{OH})$ in this study was 16.62 (SD 8.06) nmol/L lower than the cut off value of nmol/L, 12 of 30 subjects had levels of vitamin D hydroxycholecalciferol $(25 \mathrm{OH})$ $<50 \mathrm{nmol} / \mathrm{L}$. Wood et al. also found decreased levels of vitamin D hydroxycholecalciferol $(25 \mathrm{OH})<50$ $\mathrm{nmol} / \mathrm{L}$ in 13 of 2 transfusion-dependent thalassemia patients aged 1.4-25.8 years [23].

The relationship between increased serum ferritin levels and decreased serum vitamin D levels of hydroxycholecalciferol $(25 \mathrm{OH})$ is by Prapai et al.'s study on transfusion-dependent thalassemia aged 11-18 years which showed a significant relationship between increased serum ferritin levels and decreased vitamin D hydroxycholecalciferol $(25 \mathrm{OH})$.

\section{Conclusion}

In this study, we found an increase in serum ferritin levels followed by a decrease in serum vitamin D levels of hydroxycholecalciferol $(25 \mathrm{OH})$ in transfusion-dependent thalassemia patients aged 7-18 years. Screening for vitamin D deficiency in thalassemia patients can be used as a guideline in management policy so that early and effective medical care can be taken clinically to prevent further complications.

\section{Actknowledgement}

None.

\section{Financial Support}

This research received no specific grant from any funding agency, commercial or not-for-profit sectors.

\section{Conflict of Interest}

None.

\section{Ethical Standard}

This study obtained permission from the ethics committee. Ethical approval was obtained from the Institutional Ethical Committee of Dr. Soetomo general hospital (1980 / KEPK / IV / 2020). 


\section{References}

1. Borgna-Pignatti C, Cappellini MD, De Stefano P, dkk, 2005. Survival and complications in thalassemia. Ann N Y Acad Sci, 1054: 40-7.

2. Peters M, Heijboer H, Smiers F dan Giordano PC, 2012. Diagnosis and management of thalassemia. BMJ, 344(e228):1-7.

3. Noetzli LJ, Carson SM, Nord AS, Coates TD, Wood JC. Longitudinal analysis of heart and liver iron in thalassemia major. Blood 2008;112:2973-8.

4. Peng LH. Safety monitoring of the cardiac and hepatic system in beta-thalassemia patients with chelating treatment in Taiwan. Eur J Haematol 2003;70:392-7

5. Pignatti CB, Cappellini MD, Stefano PD, Vecchio GC, Forni GL, Gamberini MR. Cardiac morbidity and mortality in deferoxamine or deferiprone treated patients with thalassemia major. Blood 2006;107:3733-7.

6. Sanctis V, Roos M, Gasser T, Fortini M, Raiola G, Galati MC. Impact of long term chelation therapy on growth and endocrine functions in thalassemia. J Pediatr Endocrinol Metab 2006;19:471-80.

7. Weatherall DJ. The thalassemias. Dalam: Beutler E, Lichtman M, Coller B, Kipps T, punting. Williams hematology. Edisi ke-7. New York: McGraw-Hill; 2007.h.547-80

8. Moules A, Challa A, Chaliasos N, Lapatsanis PD. Vitamin D metabolites (25-hydroxyvitamin D, 24,25-dihydroxy vitamin D, and 1,25-dihydroxy vitamin D) and osteocalcin in beta-thalassemia. Acta Paediatr 1997;86:594-9

9. Napoli N, Carmina E, Bucchieri S, Sferrazza C, Rini GB, Di Fede G. Low serum levels of 25-hydroxy vitamin D in adults affected by thalassemia major or intermedia. Bone 2006;38:888-92.

10. Chatterton BE, Thomas CM, Schultz CG. Liver density measured by DEXA correlates with serum ferritin in patients with betathalassemia major. J Clin Densitom 2003;6:283-8.

11. Chow LH, Frei JV, Hodsman AB, Valberg LS. Low serum 25-hydroxyvitamin D in hereditary hemochromatosis: relation to iron status. Gastroenterology 1985;88:865-9.

12. Dejkhamron P, Wejaphikul K, Mahatumarat T, Silvilairat S, Charoenkwan P, Saekho S, et al. Vitamin D deficiency and its relationship with cardiac iron and function in patients with transfusion-dependent thalassemia at Chiang Mai University Hospital. Pediatr Hematol Oncol. 2018;35(1):52-9.

13. Holick MF, Binkley NC, Bischoff-Ferrari HA, Gordon CM, Hanley DA, Heaney RP, et al. Evaluation, Treatment, and Prevention of Vitamin D Deficiency: an Endocrine Society Clinical Practice Guideline. J Clin Endocrinol Metab. 2011 Jul;96(7):1911-30.

14. Cohen AR, Galanello R, Pennell DJ, Cunningham NJ, Vichinsky E. Thalassemia. Hematology 2004;121:14-34.

15. Kushner JP, Porter P, Olivieri NF. Secondary iron overload. Hematology 2001;56:47-63.

16. Beutler E, Hoffbrand AV, Cook JD. Iron deficiency and overload. Hematology 2003;145:41-61.

17. Herbert V, Jayatilleke E, Shaw S, Rosman AS, Giardina P, Grady RW, et al. Serum ferritin ion, a new test, measure human body iron stores unconfounded by inflammation. Stem Cells 1997;15:291-6

18. Wish JB. Assessing iron status: beyond serum ferritin and transferrin saturation. Clin J Am Soc Nephrol 2006;1:54-8.

19. Theil EC. Ferritin: at the crossroads of iron and oxygen metabolism. Am J Nutr 2003;133:1549-53.

20. Mazza P, Giua R, Marco SD, Bonnetti BG, Amuri B, Masi C, et all. Iron overload in thalassemia: a comparative analysis of magnetic resonance imaging, serum ferritin, and iron content of the liver. Haematologica 1995;80:398-404.

21. Brittenham GM, Badman DG. Noninvasive measurement of iron. Blood 2003;101:15-9.

22. Holick MF. Vitamin D deficiency. N Engl J Med 2007;357:266-81. 
23. Wood JC, Claster S, Carson S, Menteer JD, Hofstra T, Khanna R, et all. Vitamin D deficiency, cardiac iron, and cardiac function in thalassemia major. Br J Haematol 2008;141:891-4. 